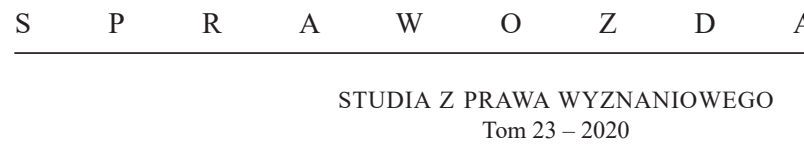

DOI: https://doi.org/10.31743/spw.12197

ANNA TUNIA*

\title{
UROCZYSTOŚĆ WRĘCZENIA KSIĘGI JUBILEUSZOWEJ DEDYKOWANEJ KSIĘDZU PROFESOROWI ARTUROWI MEZGLEWSKIEMU Z OKAZJI 60. ROCZNICY URODZIN,
} Kombornia, 22 września $2020 \mathrm{r}$.

W dniu 22 września 2020 r. w Pałacu „Dwór Kombornia” odbyła się uroczystość wręczenia Księgi Jubileuszowej dedykowanej ks. prof. zw. dr. hab. Arturowi Mezglewskiemu zatytułowanej Człowiek. Państwo. Kościót - będącej wyrazem uczczenia 60. rocznicy urodzin dostojnego Jubilata. Uroczystość ta połączona była z XVII Ogólnopolskim Sympozjum Prawa Wyznaniowego pt. Orzecznictwo w sprawach wyznaniowych, które odbyło się w Komborni w dniach 22-24 września 2020 r.

Zebranych na uroczystości gości powitał dr hab. Marek Bielecki, prof. ASzWoj - Prezes Polskiego Towarzystwa Prawa Wyznaniowego, który otwierając spotkanie złożył wyrazy uznania ks. prof. Arturowi Mezglewskiemu i wyraził przekonanie, iż Jubileusz ten będzie stanowił dla wszystkich szczególny dzień do tego, by kontemplować Jego osobę.

Następnie głos zabrał dr hab. Paweł Sobczyk, prof. UO - poprzedni Prezes PTWP i organizator spotkania - który dokonał prezentacji Księgi Jubileuszowej. Przedstawiając dzieło, odniósł się wpierw do samego jego tytułu, którego brzmienie - jak zaznaczył - prezentuje triadę bogatego życia Jubilata. Podkreślił też, iż jest ono nieco inne niż tego rodzaju publikacje, ponieważ - zgodnie z wolą Jubilata - nie ma w nim Jego zdjęcia, życiorysu, tabulatorów, listów wdzięczności czy wykazu osiągnięć naukowych, co - jak skonstatował - wynika z wrodzonej skromności Ju-

* Dr hab., prof. KUL, Katedra Prawa Pracy i Ubezpieczeń Społecznych, Wydział Prawa, Prawa Kanonicznego i Administracji, Katolicki Uniwersytet Lubelski Jana Pawła II, Al. Racławickie 14, 20-950 Lublin, e-mail: atunia@kul.pl. ORCID 0000-0002-7703-0828. 
bilata. Prof. Sobczyk opisując stronę formalną Księgi zauważył, iż liczy ona 818 stron i opublikowanych zostało w niej 40 artykułów naukowych (w tym jeden paranaukowy) napisanych przez 45 autorów. Księga wydana została nakładem Polskiego Towarzystwa Prawa Wyznaniowego i Dobrodziejów przez renomowane Wydawnictwo Naukowe „Academicon”, a jej redaktorami są - mówiący te słowa (Paweł Sobczyk) oraz Piotr Steczkowski. Odnosząc się do warstwy merytorycznej Księgi zauważył, iż tematyka ujętych w niej artykułów jest wieloaspektowa i jest odbiciem zainteresowań badawczo-naukowych i działalności społecznej Jubilata, które dotyczą kilku dziedzin prawa. Przede wszystkim: prawa wyznaniowego, prawa oświatowego, prawa o ruchu drogowym oraz prawa i postępowania w sprawach o wykroczenia. Monografia ta łączy w sobie te aspekty i bez wątpienia stanowić będzie cenną pozycję w polskiej bibliografii naukowej, czemu wyraz ufności dał prof. Sobczyk.

W następnej kolejności głos zabrał ks. dr hab. Piotr Steczkowski, prof. UR, który wygłosił niezwykle wymowną, uźródłowioną i bogatą w trafne spostrzeżenia laudację na cześć dostojnego Jubilata. Przedstawienie owej laudacji - jak zaznaczył - było zadaniem trudnym z uwagi na nietuzinkową postać ks. prof. Artura Mezglewskiego, który jest wybitnym prawnikiem, a jednocześnie osobą o niezwykle barwnej osobowości, stąd - jak dodał do jej oddania lepiej służyłby pędzel artysty malarza niż z trudem składane słowa. Prezentując sylwetkę Jubilata, ks. prof. Steczkowski odszedł od klasycznego referowania Jego biogramu, lecz forując zasadzie, w myśl której zręby naszej osobowości kształtowane są tam ,skąd nasz ród”, przedstawił postać ks. prof. Mezglewskiego odwołując się do historii, kultury i charakterystyki miejsca Jego pochodzenia. Jako motto owej prezentacji posłużyły słowa oddające obraz jestestwa Jubilata: „Nieskrępowany duch z węgierskiego traktu”, czyli „Sylwetka Księdza Profesora Artura Mezglewskiego historią Jaślisk inspirowana”. Owe Jaśliska właśnie (niewielka miejscowość w Beskidzie Niskim - „mała Ojczyzna” Jubilata), ich historia, tradycja i kultura nadały - jak zaznaczył laudator - kształt barwnej osobowości Jubilata. W odniesieniu do Jaśliszczan mówią bowiem, że „Ludzie charaktery mają tu trudne, jak ta ziemia i klimat. $Z$ jednej strony obcym nieba by przychylili, a z drugiej są czujni. I są uparci, bronią swojego zdania, czasami irracjonalnie". W słowach tych wyraża się także to, jakim człowiekiem jest ks. prof. Artur Mezglewski. Pracowity, stanowczy, dążący do wyty- 
czonych celów, a jednocześnie przewidujący, otwarty, towarzyski, przełamujący dystans i konwenanse, przyciągający do siebie innych, społecznik i podróżnik. Pomijając w laudacji potrzebę ukazywania bogatego dorobku naukowego ks. prof. Mezglewskiego, laudator odniósł się do Jego pracy na rzecz drugiego człowieka, państwa i Kościoła, które - jak w tytule Księgi jubileuszowej - odzwierciedlają troistość aktywności księdza profesora Artura Mezglewskiego. Przede wszystkim wśród nich zauważyć należy, iż ks. prof. Mezglewski stał się inspiratorem i organizatorem trzech pierwszych Ogólnopolskich Sympozjów Prawa Wyznaniowego połączonych ze zjazdem Katedr i Wykładowców Prawa Wyznaniowego, przyczyniając się w ten sposób do integracji środowiska przedstawicieli nauki prawa wyznaniowego. Był także inicjatorem powstania Polskiego Towarzystwa Prawa Wyznaniowego, zarejestrowanego w RP stowarzyszenia naukowego, skupiającego specjalistów z zakresu prawa wyznaniowego, którego celem jest propagowanie nauki prawa wyznaniowego, i w którym - przez trzy kolejne kadencje - pełnił funkcję wiceprezesa zarządu. Ks. profesor Mezglewski przyczynił się także do powstania (wysokopunktowanego obecnie) czasopisma naukowego Studia z Prawa Wyznaniowego, wydawanego przez Wydział Prawa, Prawa Kanonicznego i Administracji Katolickiego Uniwersytetu Lubelskiego Jana Pawła II, na łamach którego publikowane są opracowania naukowe dotyczące prawnych aspektów wolności religijnej oraz relacji między państwem oraz kościołami i innymi związkami wyznaniowymi. W czasopiśmie tym pełnił najpierw funkcję redaktora naczelnego, a następnie funkcję zastępcy redaktora naczelnego. Ponadto - wychodząc naprzeciw potrzebom osób pokrzywdzonych różnorakimi aktami władzy państwowej - zainspirował powstanie zarejestrowanej organizacji „Stowarzyszenie Prawo na Drodze”, w którym pełni funkcję prezesa zarządu, a którego celem m.in. jest pomoc prawna i techniczna na rzecz uczestników ruchu drogowego oraz monitorowanie procesów stosowania prawa przez organy władzy publicznej. Kończąc przemówienie ks. prof. Piotr Steczkowski złożył na ręce Jubilata gratulacje i wyrazy uznania za jego pracę i niezłomność w byciu gorliwym obrońcą w wymiarze społecznym.

Po tej wypowiedzi, słowa podziękowania, wdzięczności i uznania, a także nuty wspomnień wiążących się ze spotkaniem na swej drodze życiowej Jubilata, wyrazili między innymi: prof. zw. dr hab. Tadeusz J. Zieliński (ChAT); ks. dr hab. Dariusz Walencik, prof. UO; ks. dr hab. Tadeusz Stani- 
sławski, prof. UZ; dr hab. Jerzy Nikołajew, prof. UO; ks. dr hab. Mieczysław Różański, prof. UWM; ks. dr hab. Piotr Stanisz, prof. KUL; mgr Michaela Moravcikova (Uniwersytet w Trnawie) oraz dr hab. Maciej Mikuła, prof. UJ, który słowa te wyraził także w imieniu prof. dr. hab. Wacława Uruszczaka z UJ.

Następnie uroczystego wręczenia Księgi Jubileuszowej ks. profesorowi Arturowi Mezglewskiemu dokonali: ks. prof. Piotr Steczkowski oraz prof. Paweł Sobczyk.

W ostatnim akcie głos zabrał sam Jubilat, który wszystkim serdecznie podziękował za zorganizowanie uroczystości oraz trud włożony w przygotowanie i wydanie dedykowanej Mu Księgi. Kreśląc zaś w krótkich słowach drogę swojej kariery naukowej, dowcipnie odniósł się do wygłoszonych peanów, demitologizując swoje zasługi. 